\title{
Water and the political ecology of urban metabolism: the case of Mexico City
}

\author{
Gian Carlo Delgado-Ramos ${ }^{1}$ \\ National Autonomous University of Mexico, Mexico
}

\begin{abstract}
Today, $52 \%$ of the world's population live in urban areas and this number is expected to rise to $64-69 \%$ by 2050. Cities consume most of the world's energy and materials, and are responsible of about three quarters of direct and indirect GHG emissions. Consumption patterns, however, are asymmetrical among cities and citizens. Urban metabolism, or the analysis of energy and material flows and stocks (infrastructure) that shape settlements, allows the identification not only of the dimensions of these flows and stocks, but also their main technical and socio-ecological features. These can also be evaluated from an urban political ecology perspective, that is, in terms of power relationships that define who gets access to, or control over, natural resources and other components of urban space. This article opens with a general introduction to urbanization trends, followed by a presentation of urban metabolism and urban political ecology approaches as useful analytical tools for assessing the access, management and usufruct of water in Mexico City's Metropolitan Area. A general description of the hydropolitan region of study is then offered in order to analyze urban water flows and their socioecological implications for the water-energy nexus and climate. The article concludes with a call for a paradigm change in order to transform urban settlements towards more livable, sustainable and equitable ones; a process that demands not only paying attention to the form but also to the function of urban territories within capitalist productive relationships. In this context the design and execution of public policies needed for transforming the current trend of constructing, operating, managing, and living in cities must be proactive, imaginative, and based on an integral metabolic planning that allows the adjustment of planning and policy tools to overarching contextual changes and to historical trends and socially desirable futures. Specific recommendations include the bottom-up management of water infrastructure and the guarantee of human rights to water, sanitation and a healthy environment; these are components of the 'right to the city.'
\end{abstract}

Key words: urban metabolism, water, water-energy nexus, climate change, urban political ecology, Mexico City.

\section{Résumé}

Aujourd'hui, 52\% de la population mondiale vit en milieu urbain, et ce nombre devrait se élever à $64-69 \%$ d'ici à 2050. Les villes consomment la plupart de l'énergie et des matériaux du monde, et sont responsables d'environ trois quarts desémissions de serre directes et indirectes. Les modes de consommation, toutefois, sont asymétriques entre les villes et les citoyens. La métabolisme urbain, ou l'analyse de l'énergie et des matières flux et les stocks (d'infrastructure) qui façonnent les villes, permet l'identification des dimensions de ces flux et stocks, mais aussi leurs principales caractéristiques techniques et socio-écologiques. Ceux-ci peuvent également être évalués à partir d'une perspective de l'écologie politique urbaine, qui est en termes des relations de pouvoir qui définissent qui a accès à, ou le contrôle de ressources naturelles et d'autres composants de l'espace urbain. Cet article commence par une introduction générale aux tendances de l'urbanisation, suivie d'une présentation du métabolisme urbain et de l'écologie politique urbaine comme outils d'analyse utiles pour évaluer les droits, l'accès et la gestion de l'eau dans la zone métropolitaine de

\footnotetext{
${ }^{1}$ Dr. Gian Carlo Delgado Ramos, Senior Researcher, Interdisciplinary Research Center on Sciences and Humanities, National Autonomous University of Mexico (CEIICH, UNAM), Mexico. E-mail: giandelgado "at" gmail.com. This article was prepared as part of the Mexico City's urban metabolism assessment and its socioeconomic impacts research project, supported by the Climate Change Research Program and the Interdisciplinary Research Center on Sciences and Humanities, both of the National Autonomous University of Mexico. It was presented on July $24^{\text {th }} 2014$ at Inequality and climate change: perspectives from the South in Dakar, Senegal, supported by CODESRIA (Council for the Development of Social Science and Research in Africa), International Development Economics Associates and the Latin American Council of Social Sciences. Thankyou to the referees and editor Casey Walsh.
} 
Mexico. Une description générale de la région hydropolitan est ensuite offert pour analyser les flux d'eau urbains et leurs implications socio-écologiques pour le lien eau-énergie et le climat. L'article conclut par un appel à un changement de paradigme dans le but de transformer les établissements urbains vers les villes plus vivables, durables et équitables. Ce processus exige prêter attention à la forme, mais aussi à la fonction des territoires urbains au sein des relations productives capitalistes. Dans ce contexte, la conception et l'exécution des politiques publiques nécessaires pour construire les villes, les exploiter, la gestion et la vie quotidienne doivent être proactif, imaginatif, et basé sur une planification métabolique intégrante. Cela doit permettre le réglage des outils de planification et de politique envers les changements contextuels généraux, et aux tendances à long terme et de contrats à terme sociales souhaitables. Des recommandations spécifiques comprennent la gestion la base de l'infrastructure de l'eau, et la garantie des droits humains à l'eau, l'assainissement et un environnement sain. Ce sont des éléments des «droit à la ville».

Mots clés: métabolisme urbain, eau, nexus eau-énergie, le changement climatique, l'écologie politique urbaine, Mexico.

\section{Resumen}

Hoy día, 52\% de la población vive en áreas urbanas, cifra que se espera aumente a 64-69\% para el 2050. Las ciudades consumen el grueso de la energía y materiales a escala global y son responsables de alrededor de tres cuartas partes de las emisiones directas e indirectas de GEI. Los patrones de consumo, sin embargo, son asimétricos entre ciudades y sus habitantes. El metabolismo urbano o el análisis de flujos de energía y materiales y del stock (infraestructura) que da forma a los asentamientos, permite identificar no sólo las dimensiones de esos flujos y stocks, sino además, sus principales características técnicas y socio-ecológicas. Ésas, pueden también evaluarse desde la perspectiva de la ecología política, es decir, en términos de relaciones de poder que definen quién tiene acceso a, o control de, los recursos naturales y otros componentes del espacio urbano. Este artículo abre con una introducción general sobre las tendencias de urbanización para luego presentar las perspectivas de metabolismo urbano y ecología política como herramientas útiles para valorar el acceso, gestión y usufructo del agua en la Zona Metropolitana del Valle de México. Se ofrece una descripción general de la región hidropolitana de estudio con el objeto de analizar los flujos de agua y sus implicaciones socioecológicas en términos del denominado nexo agua-energía y, por tanto, del clima. El trabajo concluye con un llamado de cambio de paradigma para poder transformar los asentamientos urbanos hacia aquellos más vivibles, sustentables y equitativos; proceso que demanda no sólo atender la cuestión de la forma pero también de la función de los territorios urbanos en el marco de las relaciones capitalistas de producción imperantes. En este contexto el diseño y ejecución de políticas públicas necesarias para transformar la actual tendencia de construir, operar, manejar y vivir en las ciudades debe ser proactivo, imaginativo y basado en una planeación metabólica integral que permita ajustar las herramientas de planeación y de política ante los cambios contextuales y las tendencias históricas, así como a los futuros socialmente deseables. Entre las recomendaciones específicas, se incluye el manejo de abajo hacia arriba de la infraestructura de agua y la garantía de los derechos humanos al agua, saneamiento y a un ambiente sano; esto es, a componentes del 'derecho a la ciudad.'

Palabras clave: metabolismo urbano, agua, nexo-agua energía, cambio climático, ecología política urbana, Ciudad de México.

\section{Introduction}

Today, 52 percent of the world's population live in urban areas. By 2050, this figure is expected to rise to 64 69 percent (United Nations 2012). By that time, the size of urban areas is expected to have doubled or even tripled, depending on population and economic dynamics (Angel et al. 2011; Seto et al. 2014).Cities consume between $67 \%$ and $76 \%$ of total world energy and are responsible for $71 \%$ to $76 \%$ of direct and indirect greenhouse gas (GHG) emissions (Seto et al. 2014). However, the 380 developed-region cities in the top 600 by GDP accounted for 50\% of global GDP in 2007 with more than 20\% of global GDP coming from 190 North American cities alone (Dobbs et al. 2013: 1). This positions these cities as practically the greatest consumers on the planet, while the rest of urban settlements play a minor role. This is supported by the fact that although human urban settlements are growing at a rate of approximately $2 \%$ per year, with outliers of $0.7 \%$ for some developed countries and 3\% for some developing areas (United Nations 2012), this growth is not proportional to the amount of emissions that can be attributed to each case. Currently, urban settlements that are similar in terms of the number of inhabitants per $\mathrm{km}^{2}$ have very different GHG contributions-both 
historical and nominal (see Figure 1 for a comparative analysis of nominal emissions). Although, on one hand, this divergence occurs partially in response to various factors such as land use, settlement form and extension, the length of time a settlement has existed, or the biophysical conditions of each case (e.g., latitude, proximity, and resource availability), on the other hand, the polarization between cities and between inhabitants continues to be significant not only in economic terms but also in the terms of energy and material consumption patterns. As we shall see, this is certainly the case of Mexico City.

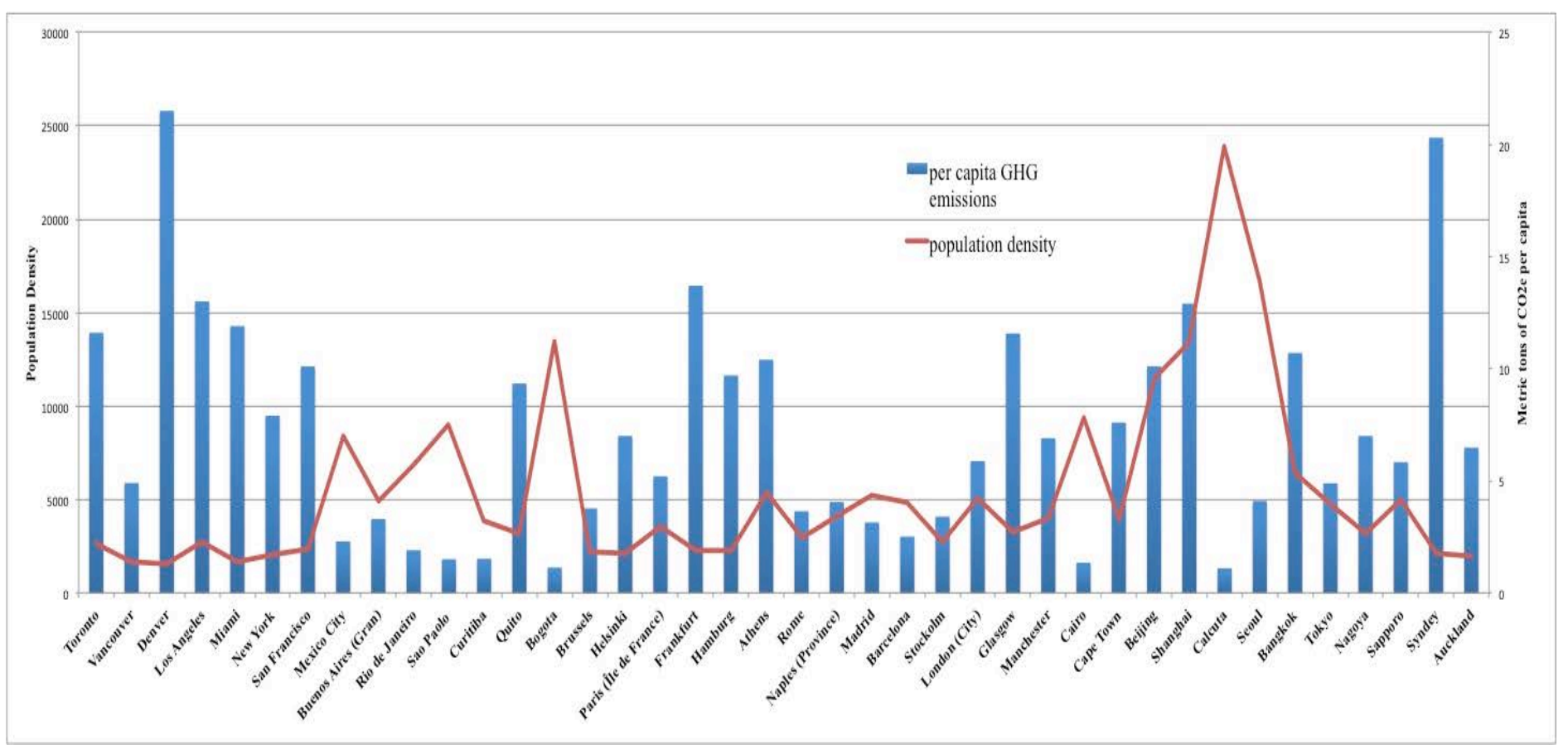

Figure 1: Per capita GHG emissions versus population density for selected cities. Source: author's compilation based on climate change action plans of selected cities and on UN-Habitat and World Bank databases. Mexico City is the eight bar from the left.

\section{Urban metabolism and urban political ecology}

The unsustainable character of urban settlements is clearly visible when verifying their metabolic profiles, meaning "...the process of contiguous de-territorialization and re-territorialization through metabolic circulatory flows organized through social and physical conduits" (Swyngedouw et al. 2005: 22). ${ }^{2}$ This kind of analysis considers cities as open systems, built environments that demand exchanges of matter (biotic, abiotic) and energy (renewable or non-renewable) with their hinterlands and beyond. Such exchanges occur in two ways: as inflows of materials and energy from outside of the (urban) system, and flows of depleted energy and materials that are disposed inside but mainly outside of the urban system (see Figure 2). Since outflows are of different kind, not only in terms of biophysical composition but also on their lifespan, an urban stock, or the material dimension of urban systems is considered as well. This can be observed throughout three general components of integral urban metabolic analyses:

(1) energy and material flows and material stock configuration;

(2) processes by which those take place; and

\footnotetext{
${ }^{2}$ For Swyngedouw (Swyngedouw et al. 2005: 22 and 25), "metabolic circulation" refers to the merging of existing (bio)physical dynamics with the set of conditions that regulate and frame current social relations of production in this or that territorial space.
} 
(3) the specific social relations of production that shape metabolic profiles and the built environment.

The initial focus of urban metabolic studies was limited to material flow analysis, followed by energy flow analysis (what is called the linear metabolic model) and, later on, by the so-called cyclic flow model that incorporates the notion of relative 'closed material cycles' (recycling processes and/or partial recovery of outflows) (Baccini and Brunner 1990; Brunner and Rechberger 2005; Haberl 2001). With time, authors incorporated internal analyses of components for each flow, as process networks (Zhang 2013); this is for instance the type of analysis offered below on urban metabolism and political ecology of water in Mexico City and its metropolitan area. Finally, the analysis of urban stocks has recently been included as an important additional aspect of urban metabolism studies, not only because of their relevance in terms of potential future material availability (through increasing and planning closing material cycles over scales of time and space), but also because they may be seen as an additional path for increasing urban sustainability and climate change mitigation (Seto et al. 2014).

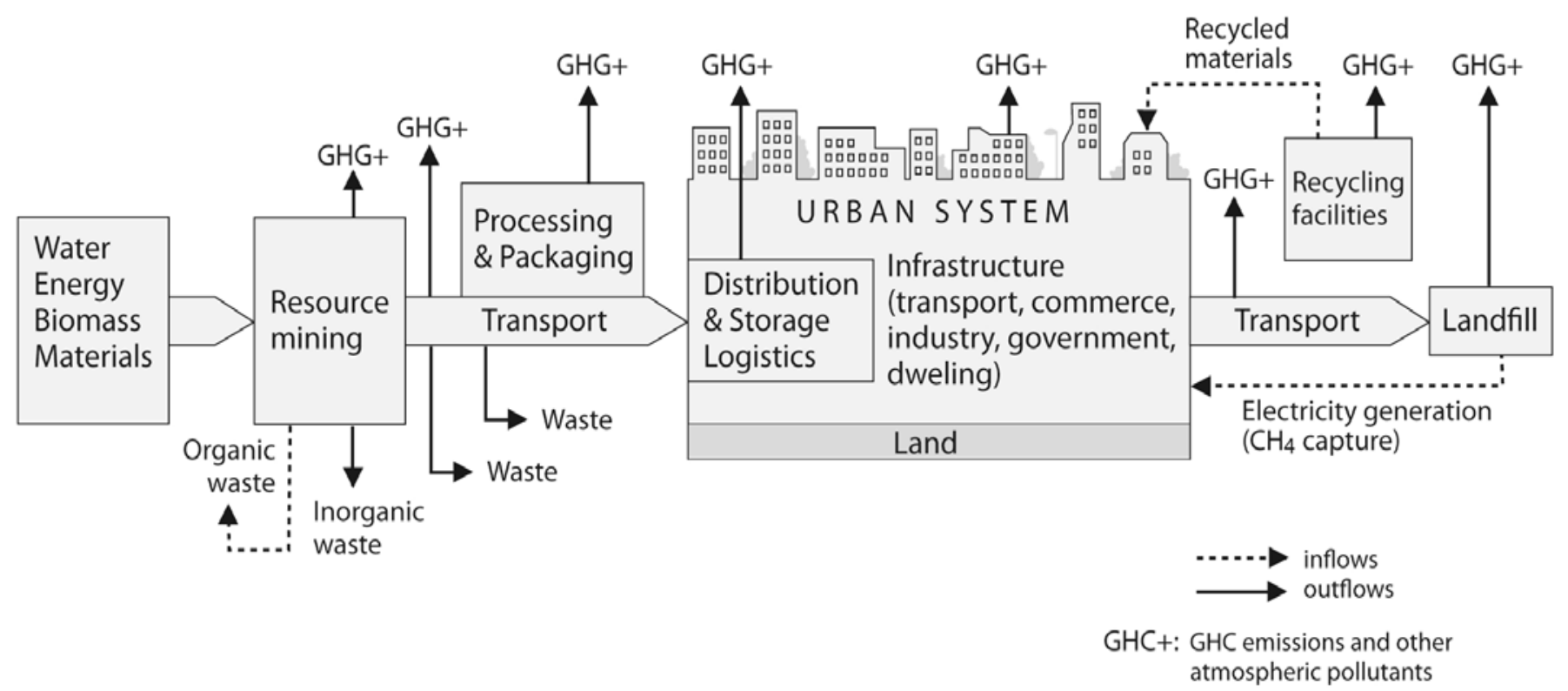

Figure 2: Urban metabolism framework: the urban biophysical flow. Source: author's own elaboration. Graphic design: Ángeles Alegre-Schettino.

Wolman's work is considered pioneering in empirical terms as it analyzed energy and material flows into and out of a hypothetical 1960s United States city populated by 1 million inhabitants. Wolman properly grasped the complexity and variability of metabolic flows: such a city would require 625,000 tonnes of water and generate 500,000 tonnes of sewage daily. In addition, 9,500 metric of fuel and 2,000 tonnes of food would be required per day (Wolman, 1965). Water has been identified since then as the major urban flow in terms of volume. Diverse analyses of actual existing cities were later completed, mostly in developed countries and focusing, as mentioned, on various metabolic flows (water, food, energy, etc.). The contributions made by Baccini and Bruner (1990 and 2012) as theoretical and methodological precursors, and later on by Kennedy et al. (2007, 2009 and 2011) and Minx et al. (2010), are notable because they provide a broad, integrated view of the evolution of urban metabolism research. In Latin America, the case of Bogota has been examined in detail (Díaz-Álvarez 2011), while a generic comparative assessment has been carried out for the region's megacities and other capital cities (Delgado-Ramos 2013; Delgado-Ramos et al. 2012). Table 1 summarizes the daily per capita metabolic profile of Mexico City and its metropolitan area. This is relevant for Section Three, which analyses in detail the case of water inflows and outflows of Mexico City 
and its metropolitan area, including the energy-water nexus and its implications for climate change, and then offers a revision of the political ecology in play. Data in Table 1 is a product of a mixed exercise of top-down and bottom-up approaches. While energy, water and wastewater flows, sectorial emissions, indirect emissions from urban stock renovation and waste flows have been estimated or mined from official reports at the metropolitan or city level (a bottom-up approach), bottled water and food flows have been estimated from national average data (a top-down approach). It is notable that indirect GHG emissions from urban stock renovation are usually not taken into account in current urban GHG inventories even though they formally are considered within the Scope 3 category of the International Standard for Determining Greenhouse Gas Emissions for Cities. ${ }^{3}$

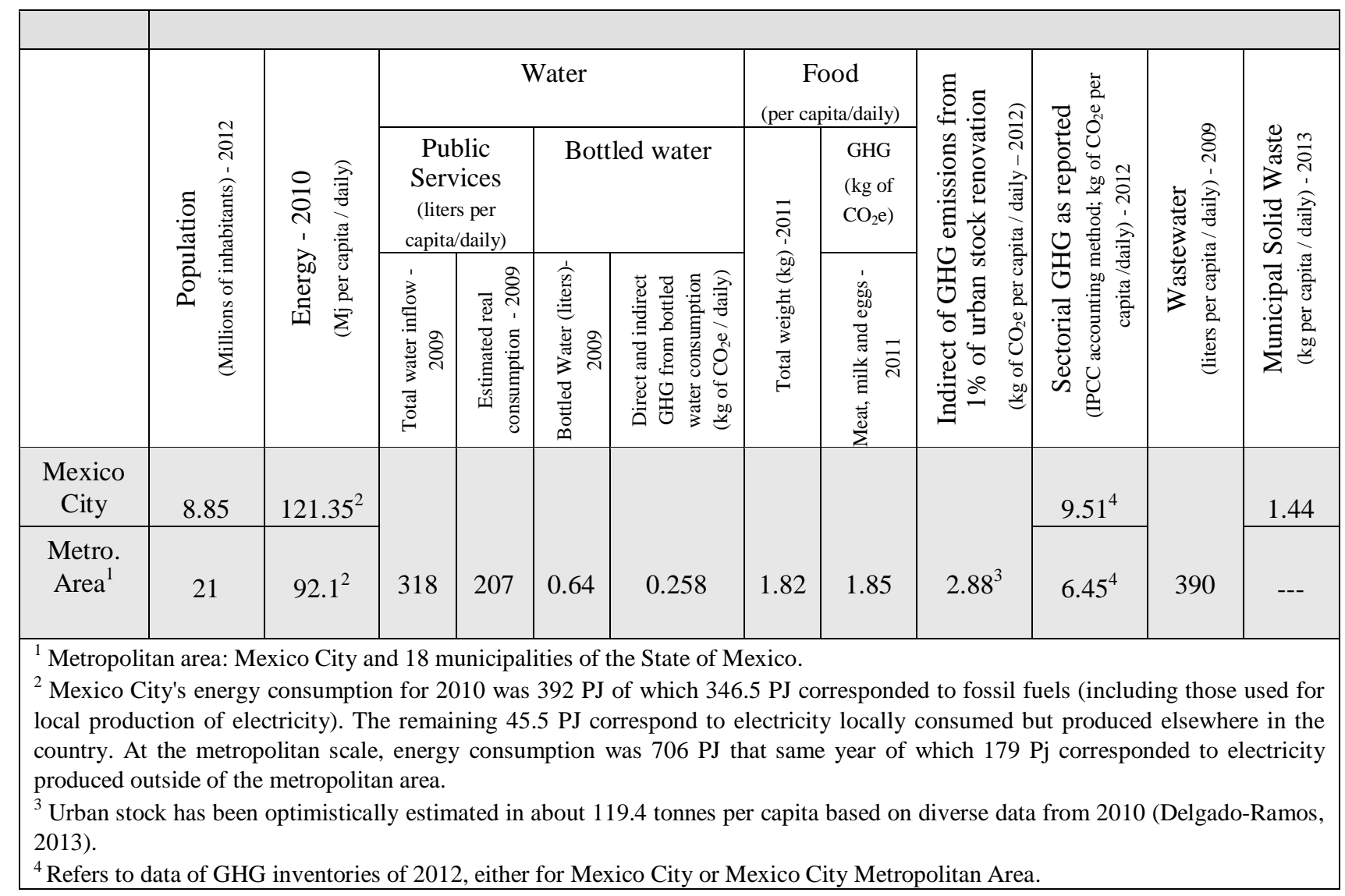

Table 1: Per capita metabolic profile of Mexico City (the smaller non-metropolitan area). Source: author's own elaboration (adjusted from Delgado-Ramos, 2013 and based on DelgadoGarcia (ed.) 2014; SMA-DF 2012; SEDEMA 2013, 2014; and FAOSTAT national food balance data of 2011). Graphic design: Ángeles Alegre Schettino.

Metabolic profile analyses of urban settlements such as this one allow the modeling of more-or-less efficient routes for using resources and managing waste and, consequently, they help focus efforts to better plan metabolic dynamics. Starting from the design of infrastructure itself (or the so called 'urban stock'), improvements can be promoted through government incentives, or even restrictions or coercive methods. Indeed, the metabolic challenge is to identify more efficient approaches towards better-integrated human

\footnotetext{
${ }^{3}$ See: $\underline{\text { www.unep.org/urban_environment/PDFs/InternationalStd-GHG.pdf }}$
} 
settlements, all with the purpose of minimizing per capita and total consumption of energy and materials. ${ }^{4}$ Ferrão and Fernandez (2013) call this metabolic planning the "sustainable urban metabolism", which addresses the prevailing need for reducing GHG emissions that, since 1970, are mostly (up to 78\%) due to burning fossil fuels and industrial processes - both are intrinsically part of urban nature (Seto et al. 2014).

Urban metabolism, a potent analytical tool of the biophysical dimension of urban settlements, must be complemented with a socio-political analytical tool such as urban political ecology in order to identify causes and processes leading to inequalities between rich and poor, or in other words, the nature of the production of space that defines the socio-political and biophysical conditions suitable for capital accumulation and thus uneven development (Harvey 1996). Furthermore, it must be kept in mind that usually urban configurations are, at some point, outlined by land dispossession, grabbing, and speculation, followed - especially in a neoliberal context - by a much-more intense privatization of common goods and state properties, including basic infrastructure for providing public services and amenities: from water, sanitation, energy and transportation to green spaces. Hence, it can be said that cities are built to a significant degree under the impulses of what Harvey (2003, 2004) has called accumulation by dispossession. It is a process that is possible with the support (or the 'absence') of the State, and it allows not only the segregation and gentrification of certain neighborhoods as well as the uneven erosion of public services and space, but also a general loss of urban resilience and therefore an increase in vulnerability. This is, for example, an outcome of land speculation, irregular urbanization and/or the loss of surrounding conservation spaces which have important ecological and climate functions for cities, such as the preservation of local biodiversity, water infiltration, carbon capture and cooling, among other so-called 'ecological services.' Yet, such negative outcomes permit an appealing accumulation of capital based on a profoundly unequal model of the production of space, that privatizes benefits and socializes costs of all kinds, including those of socio-ecological nature. In this context the increasing construction of gated communities can be seen as the asymmetrical appropriation of the positive aspects of life in the city by the middle and upper classes. Social resistance contending for a right to the city - a more equal, sustainable, inclusive, equitable, and supportive city have given rise to urban political ecology, since the revindication of said right involves the social right to manage metabolic circulatory flows (Swyngedouw et al. 2005).

As urban political ecology acknowledges, in current capitalist social relationships of production "...the material conditions that comprise urban environments are controlled, manipulated and serve the interests of the elite at the expense of marginalized populations" (Swyngedouw et al. 2005: 6). Accordingly, and due to deep-rooted dominant power relationships, energy and material flows and stocks are unequally appropriated through market relationships or even by straightforward dispossession.

The consequence of unequal purchase capacities is that the best buildings, the highest-quality services, and the majority of increasingly privatized public space, are conferred on the 'best' consumers, that is, to the upper and middle classes. Concurrently, the negative externalities of urban life tend to be exported as much as possible to poor or peripheral neighborhoods, or outside the city. Questions of class, race, and ethnicity are thus central to the question of who does and who doesn't get access to, or control over natural resources and other components of the urban space (Swyngedouw et al. 2005), as well as the imposition of the socioenvironmental impacts that arise.

\section{Urban metabolism and the political ecology of water: the case of Mexico City and its Metropolitan Area}

An analysis of Mexico City supports a better understanding and empirical evidence of water and the political ecology of urban metabolism. The hydropolitan region (Perló and González 2009) of the Mexico City Metropolitan Area (ZMVM, for its acronym in Spanish) is a territorial unit that Peña (2012) prefers to call the city-basin, which refers to the interconnection of four basins that are not naturally related in any way: the Valley of Mexico, Alto Lerma, Cutzamala, and Tula basins. In this geographical area the hydrosocial

\footnotetext{
${ }^{4}$ It is notorious that "green economy" policies only pay attention to per capita efficiency or at the level of sub-components of the system. Since such relative efficiency does not guarantee an absolute efficiency, a rebound effect is a usual outcome.
}

Journal of Political Ecology $\quad$ Vol. 22, 2015 
cycle (Swyngedouw et al. 2005) - that is, the particular management of water in a given socio-environmental context - has resulted in the appropriation/dispossession of clean water from neighboring basins and the expulsion of sewage towards another. While the first three basins supply water inflows, the last (Tula) is the destination of water outflows, including rainwater that has historically led to the flooding of certain areas of construction in the Valley of Mexico. The flooding is due not only to urban expansion itself, but also to the fact that the city is located over an endorheic (closed basin) water system. The Valley of Mexico was once a vast lake and has been progressively drained since the colonial period, beginning specifically with the construction of the Huehuetoca Royal Chanel (1607), the Nochistongo Tajo (1789), the first (1905) and second (1954) Tequixquiac tunnels, the deep drainage system (1975), and the recent Emisor Poniente deepTunnel (2010). By 2010 the system as a whole allowed the expulsion of some $57 \mathrm{~m}^{3} / \mathrm{s}$, keeping settled lands dry that were once part of the lake.

It should be mentioned as well that, given climate change, rains have become more intense over shorter periods, increasing water precipitation from $600 \mathrm{~mm}$ in 1900 to $900 \mathrm{~mm}$ at the end of the first decade of the $21^{\text {st }}$ century (data from the Tacubaya meteorological station have registered a $7 \%$ increase in water precipitation just since 1979). This situation, compounded with the climate change projection for 2050 regarding an increased amount and intensity of rainfall, especially during the rainy season (Aponte 2013), makes it necessary to constantly renovate and improve the water supply system, as well as the tunnels, deep tunnels (emisores), and the deep drainage system that expels water outside the Valley, as there is a direct relationship with the degree of the city's vulnerability to water availability (during dry seasons) and flooding (during rainy seasons). ${ }^{5}$ In spite of this, the increase in the amount and intensity of rainfall by 2050 does not necessarily mean there will be sufficient water to cover projected metropolitan demands, which are growing (Aponte 2013). In order to better understand this condition it is necessary to analyze current water urban metabolism dynamics.

\section{Inflows}

As Figure 3 shows, Mexico City Metropolitan Area water inflows mainly come from:

1) More than 600 wells that extract water from the Valley of Mexico aquifer (approximately $59 \mathrm{~m}^{3} / \mathrm{s}$ ) which is currently being overexploited causing up to a $1 \mathrm{~m}$ drop per year in the static water level (with a deficit of approximately $\left.28 \mathrm{~m}^{3} / \mathrm{s}\right)^{6}$;

2) The Lerma and Cutzamala basins system (approximately $5 \mathrm{~m}^{3} / \mathrm{s}$ and $15 \mathrm{~m}^{3} / \mathrm{s}$, respectively); and urban rivers and springs (approximately $2 \mathrm{~m}^{3} / \mathrm{s}$ ) (Burns 2009).

Together these sources supply the bulk of water that is distributed by two administration entities: Mexico City's Water System (SACMEX) ${ }^{7}$ in the Federal District, and the State of Mexico Water Commission (CAEM), which delivers water to the corresponding metropolitan municipalities throughout the State of Mexico. Other minor sources include water self-supply systems, an irregular water-truck delivery service (independent of the above government entities), and clandestine wells, the exact number of which are unknown but estimated at around 2,250 (Peña 2012).

\footnotetext{
${ }^{5}$ Flooding is the major vulnerability of Mexico City's Metropolitan Area. It is aggravated by climate change, as recognized in the current Mexico City climate change action program (2014-2020), which identified 5.6 million inhabitants under potential risk. Certain areas of the city demonstrate consistent flooding; including the overflow of wastewater in areas such as Valle de Chalco, Nezahualcóyotl, Cuatitlán, and Ixtapaluca caused by a lack of sanitation in the city's drainage system and by rains that increase in intensity. In Mexico City, vulnerable boroughs are Gustavo A. Madero, Venustiano Carranza, Iztacalco, Iztapalapa, Tláhuac, Cuauhtémoc, Coyoacán, Azcapotzalco y Benito Juarez.

${ }^{6}$ The aquifer is currently overexploited. The historic level of water extraction is estimated at $2 \mathrm{~m}^{3} / \mathrm{s}$ for 1870 ; approximately $22 \mathrm{~m}^{3} / \mathrm{s}$ for 1952 (which already shows a deficit, as there was only $19 \mathrm{~m}^{3} / \mathrm{s}$ of recharge); and some $59 \mathrm{~m}^{3} / \mathrm{s}$ extracted by 2007 (Burns 2009).

${ }^{7}$ The Mexico City Water System is an entity that articulates private concessionaries of the water public service, geographically arranged in four operating areas: 1) Proactiva Media Ambiente SAPSA of the Mexican ICA and the French Veolia company; 2) Industrias del Agua de la Ciudad de México S.A. de C.V. of the Mexican Peñoles and French Suez; 3) Tecnología y Servicios de Agua S.A. de C.V., which is also the property of Peñoles and Suez; and 4) Agua de México, S.A. de C.V., of the national capital.
} 


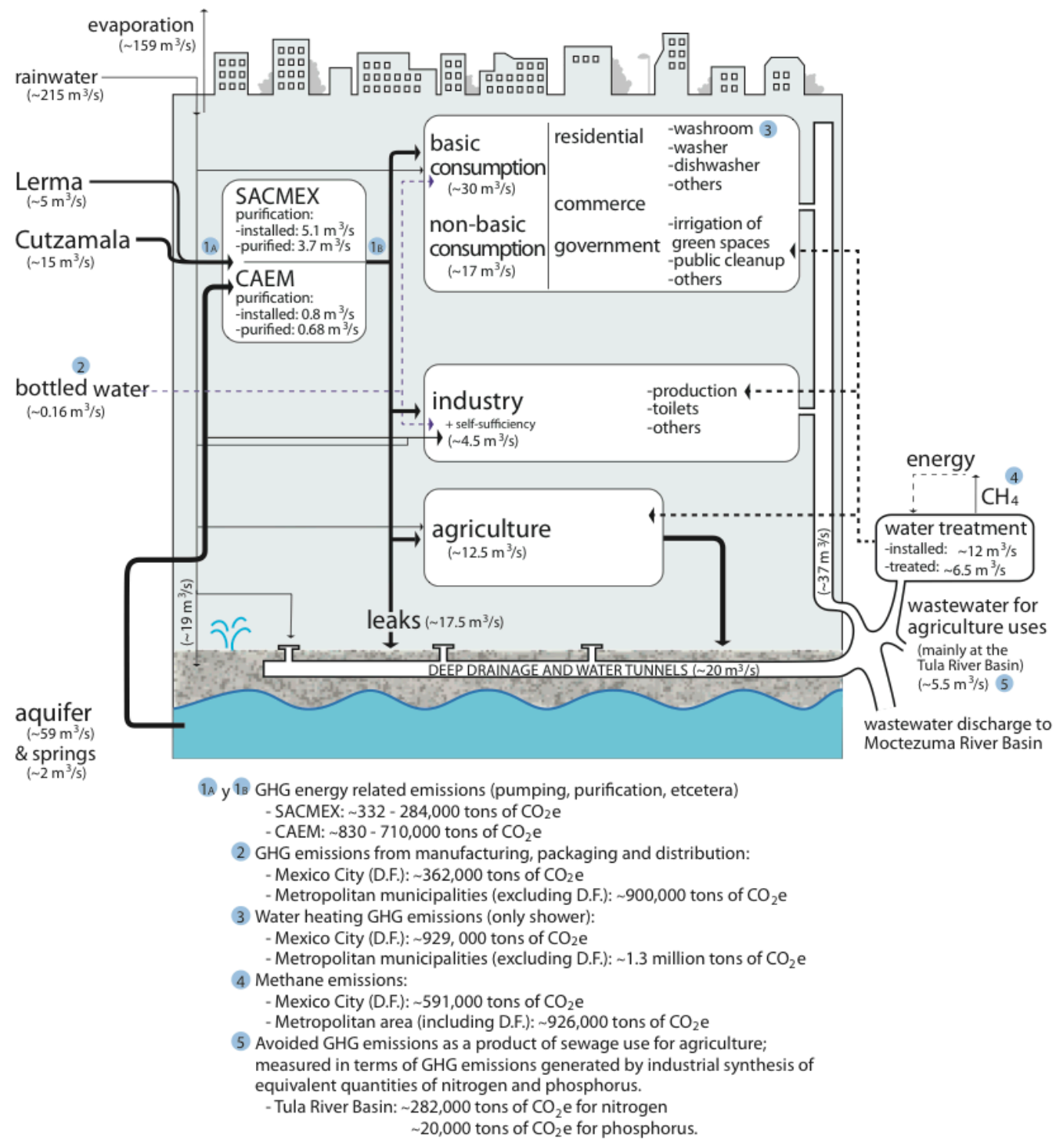

Figure 3: Urban water metabolism of the Mexico City Metropolitan Area (ZMVM). Source: author's own elaboration based on Burns 2009; Delgado-Ramos 2014b; SM-DF 2012; EMARNAT/CONAGUA 2012; and date from INFO-DF, local access public information entity. Graphic design: Ángeles Alegre-Schettino.

In addition, the Mexico City Metropolitan Area imports bottled drinking water from several places, the bulk of which are national. Bottled water consumption by the Federal District has been estimated at 2.07 $\mathrm{hm}^{3} /$ year $^{8}$, and that of the metropolitan municipalities officially part of the states of Mexico and Hidalgo, estimated at $3.1 \mathrm{hm}^{3} /$ year. Together, this represents an inflow of approximately $0.16 \mathrm{~m}^{3} / \mathrm{s}$, however, total demand for bottled water in the metropolitan area (ZMVM) has been calculated at $8.78 \mathrm{hm}^{3} /$ year when

${ }^{8} 1 \mathrm{hm}^{3}=1,000,000 \mathrm{~m}^{3}=1$ gigalitre (GL). 
including what is called virtual water, which is the additional water necessary for its production. ${ }^{9}$ At this point it should be noticed that $76.94 \%$ of the Federal District's population consume bottled water, while only $10.84 \%$ boil tap water; $4.37 \%$ filter or purify tap water by using other methods, and $4.58 \%$ consume it directly from the tap (Jiménez et al. 2011). Similar patterns of consumption are seen in the rest of the metropolitan area.

Without including bottled water, water consumption in the Federal District averages some 318 liters per capita/daily, but losses of between $35 \%$ and $40 \%$ due to leakage must be subtracted from this number (Jiménez et al. 2011; Peña 2012). ${ }^{10}$ In environmental terms, this is a significant issue, especially when taking into consideration that about one-third of the total water consumed by the metropolitan area comes from the Lerma-Cutzamala system, and must be pumped more than 1,100 meters vertically to reach the city. The energy used for this purpose represents $80 \%$ of the system's operating cost (Aponte 2013). Moreover, in the case of the Lerma system, installed capacity has been reduced from $15 \mathrm{~m}^{3} / \mathrm{s}$ to approximately $5 \mathrm{~m}^{3} / \mathrm{s}$ due to land subsidence registered throughout the system as a result of over-pumping the aquifers of the region. This overpumping has also contributed to the increase in the cost of moving water from low areas of the system to higher areas.

Besides all these difficulties and the economic and environmental costs just mentioned, it is noticeable that water availability is greatly asymmetrical: distribution ranges from 177 liters in the Borough of Tláhuac to 525 liters in Cuajimalpa. Boroughs with the highest incomes fall within the consumption range of 400 liters to 525 liters per capita daily; all in a context of a highly limited natural water availability of just $160 \mathrm{~m}^{3}$ per capita, yearly (based on Jiménez et al. 2011). ${ }^{11}$

In addition to water access inequalities in terms of quantity, there are disparities in terms of its quality (Jiménez et al. 2011; Díaz-Santos 2012); a reality that echoes SACMEX's purification capacity limitations. The entity has 38 purification plants in operation with an installed capacity of $5.1 \mathrm{~m}^{3} / \mathrm{s}$, but an actual purified flow rate of only $3.7 \mathrm{~m}^{3} / \mathrm{s}$ (INEGI 2014; SEMARNAT/CONAGUA 2012). There are three additional plants (two in Chimalhuacan and one in Tlamanalco) corresponding to Mexico State municipalities belonging to the Mexico City Metropolitan Area, and these plants have a total installed capacity of $0.8 \mathrm{~m}^{3} / \mathrm{s}$ with an actual flow rate of $0.68 \mathrm{~m}^{3} / \mathrm{s}$ (SEMARNAT/CONAGUA 2012).

\section{Outflows}

Metropolitan water outflows (see Figure 3) have been estimated at an average volume of $57 \mathrm{~m}^{3} / \mathrm{s}$, most of which are not treated. Installed treatment capacity in Mexico City is about $6.7 \mathrm{~m}^{3} / \mathrm{s}$, with an actual treated flow rate of only $3 \mathrm{~m}^{3} / \mathrm{s}$, while in the municipalities of the State of Mexico belonging to the metropolitan area, the installed capacity is about $5.1 \mathrm{~m}^{3} / \mathrm{s}$ with an actual treated flow rate of $3.6 \mathrm{~m}^{3} / \mathrm{s}$ (based on SEMARNAT/CONAGUA 2012). The remaining wastewater and storm water is taken to the Tula Basin (Tula-Moctezuma-Pánuco River) via the aforementioned deep drainage system and the Grand Canal. Up to $60 \%$ of this flow may in the future be treated at the Atotonilco treatment plant in the state of Hidalgo, one of the largest treatment facilities in the world, currently under construction. ${ }^{12}$

Most of the treated water in the Federal District is used in urban green spaces (83\%), and the remainder is reused by industry (10\%) or in producing food in peripheral urban areas (5\%). Treated water in the State of Mexico's municipalities is used for agricultural activities. It is important to note that the water

\footnotetext{
${ }^{9}$ Estimate based on 2009 national per capita consumption of 235 L/year (Delgado-Ramos 2014b). Average indirect water demanded for each liter of bottled water, or virtual water, has been estimated at 700 additional milliliters according to figures provided by FEMSA Coca-Cola and Nestlé Mexico in 2010.

${ }^{10}$ Even when most water losses are attributable to leakages, a fraction might be attributed to water meter misreading, inaccurate estimations of illegal extractions, and other causes.

${ }^{11}$ About 38.4\% of the Mexico City's population receives water only a few hours per day, while 61.5\% receive it all day. Yet, on average, $52 \%$ to $53 \%$ of the poorest and moderately poor areas of the city receive water only a few hours per day. This figure is only $18 \%$ to $19 \%$ in the least-poor areas where in addition most of inhabitants have economic means to invest on proper dwelling water tanks and pumping infrastructure (Jiménez et al. 2011).

${ }^{12}$ Operated by DEAL, a company owned by Carlos Slim, is supposedly capable of treating $60 \%$ of the metropolitan sewerage at an energy cost of 166 million $\mathrm{kWh} /$ year and an average generation of $917 \mathrm{t}$ of sludge daily. The plant is expected to come into operation in February 2015. It is located in the ejido of 'Conejos', right in the middle of a road that links the San Antonio and San José neighborhoods, both lacking in basic water and sanitation services.
} 
treatment process is a key issue, two central reasons. On the one hand it is important for environmental and sanitary reasons, but on the other it allows the private sector, in principle, to define who receives treated water and who doesn't (unless regulations indicate otherwise). Peña (2012) has already raised concerns about future de facto privatization of treated water.

Socio-environmental justice movements and the urban political ecology of water

The political ecology of water in the Valley of Mexico is particularly intense, due to limited availability of the liquid in the face of a strong demand, generated mainly by an accelerated urbanization process over the last few decades. It is thus no coincidence that a review carried out nationwide in Mexico between 1990 and 2002 of some 5,000 newspaper articles on water conflicts found that $49 \%$ of them took place in the Valley of Mexico (Jiménez et al. 2011). Social mobilizations included public demonstrations and facility takeovers. About $56 \%$ were due to a lack of water delivery and $24 \%$ to a hike in prices. In the metropolitan area the districts that experienced the most social unrest were precisely those with less access to water due to a lack of sufficient infrastructure, such as certain areas of the east of Mexico City and the adjoining urban zones such as Cerro de la Estrella in Iztapalapa borough (Jiménez et al. 2011).

There are other conflicts in areas where water is captured (urban water inflows) or expelled (urban water outflows). In the 1970s there were rural mobilizations against the construction of the Lerma system infrastructure in the Toluca Valley, because it signified the potential loss of harvests due to a lack of water that would instead be sent to the Mexico City Metropolitan Area. This conflict was 'solved' with the payment of damages, at first using corn and later money, but the loss of water and productive agricultural land - along with intensive industrial growth - soon revealed the socio-ecological impacts of this water transfer system.

In 1990, another conflict arose in the Temascaltepec area, where an expansion of the Cutzamala system was planned in order to obtain an additional $5 \mathrm{~m}^{3} / \mathrm{s}$. The project was halted due to social mobilization (Jiménez et al. 2011). In 2003, the improper operation of Villa Victoria Dam, part of the Cutzamala system, flooded 300 hectares of cropland, an event that led to a rural protest seeking to obtain economic compensation. Due to a lack of government response, the social movement revindicated its indigenous identity, emerging as the Mazahua Women's Army in Defense of Water (Ejército de Mujeres Mazahuas por la Defensa del Agua). Having gained society's attention with a strikingly pacifist social movement, the public was made aware of the lack of water in Mazahua communities due to the appropriation of large quantities for the Mexico City Metropolitan Area. ${ }^{13}$ Further conflicts could be mentioned, the most recent one in May of 2014, in San Bartolo Ameyalco, where a struggle emerged due to the state piping water from a local spring to transfer it to the Cutzamala system.

Other water battles relate to 'wastewater usufruct', meaning wastewater capture for treatment and the ensuing takeover of a large quantity traditionally used for crop production, which in our case study mostly applies to the Mezquital Valley in the State of Hidalgo. This is a region with very low national levels of rainfall (400 mm/year), yet some 85,000 to 90,000 hectares are cultivated and irrigated by using untreated wastewater directly, which in turn has about 44,000 tonnes of nitrogen and 17,000 tonnes of phosphorus (Burns 2009). In 2011 the Irrigation Water of Agricultural and Cattle Producers Union (Unión Productora Agrícola y Ganadera de las Aguas para Riego) denounced - once again - a wastewater flow reduction (up to two-thirds) and hence the loss of vegetable production and alfalfa. The episode gave rise to proclamations such as iwastewater is ours! (Jornada, La. 2011), reflecting the intensification of local conflicts between upland and lowland farmers, both seeking to use the 'white waters' (clean water) from the Requena and Endhó dams and the 'black waters' discharged from Mexico City Metropolitan Area. In 2013 some 75,000 producers again protested against the lack of wastewater (Montoya 2013). Furthermore, concerned about the installation of the Atotonilco treatment plant, the Council of Users in Defense of Wastewater (Consejo de Usuarios en Defensa de las Aguas Negras) have already demanded that the local Congress of Hidalgo request that the National Water Commission (CONAGUA) provide an official document that could guarantee a volume of

\footnotetext{
13 The Mazahuas movement also opposed the then-new National Water Act, which excluded community water management systems in indigenous territories. In spite of being addressed later and criminalized, this social struggle still continues (Ávila-García, 2011).
}

Journal of Political Ecology $\quad$ Vol. 22, 2015 
free wastewater for its croplands equal to the volume currently being used. This is because the possibility exists that they will be charged for treated water (News Hidalgo 2012).

\section{The water-energy nexus: a climate change challenge}

Water-energy nexus analyses, assembled from an urban metabolic perspective, allow the identification of linkages among multiple components that comprise urban water systems. Such an approach is useful for delivering an integrated vision, but when accounting for GHG emissions it does not correspond to IPCC standards. For example, in IPCC methodology electricity for water pumping is taken into account as part of a government inventory; energy for heating water is placed within the community inventory (for the residential sector); direct and indirect emissions of bottled water are considered within the community inventory (the industry and transport sectors); and avoided emissions through the use of waste water for crop production are usually not discounted. Therefore, from a metabolic approach, GHG accounting is intended to better understand the complexity and broad implications of particular metabolic flows. This is useful for water policy-making as it allows the identification of opportunities and synergies that from a traditional sectorial approach are not necessarily evident.

In 2013 Mexico City's Water System (SACMEX) used a total of 570.98 million kWh with which, among other things, 715,141.8 million liters of the total 953,522 million liters of distributed water was pumped (the remaining volume was moved by gravity) (INFODF 2014). As indicated in Figure 3, $\mathrm{CO}_{2} \mathrm{e}$ emissions from water inflows in 2013 reached 0.298 grams to 0.349 grams per liter of water managed by SACMEX, giving an annual total of about 332,000 to 284,000 tonnes of $\mathrm{CO}_{2} \mathrm{e} .{ }^{14}$ Estimates for the conurbanized municipalities served by the CAEM suggest a range of about 830,000 to 710,000 additional tonnes of $\mathrm{CO}_{2} \mathrm{e} .{ }^{15}$

Total metropolitan emissions of methane in terms of $\mathrm{CO}_{2} \mathrm{e}$ emissions from wastewater outflows have been estimated for 2010 at $~ 1.5$ million tonnes of $\mathrm{CO}_{2} \mathrm{e}$, of which 591,000 tonnes of $\mathrm{CO}_{2} \mathrm{e}$ correspond to the Federal District (SMA-DF 2012).

End-user emissions, among which residential emissions play the greatest role, must be added to the this. This energy use corresponds to water heating/cooling. In the case of Mexico, the Ministry of Energy (SENER 2013) considers that water heating alone represents at least $13 \%$ of the total amount of energy consumed in this sector and is the third-highest domestic expense.

Energy consumption for heating water in Mexico City Metropolitan Area has been estimated at $31.2 \mathrm{Pj}$ or $46 \%$ of the total amount of energy consumed in the residential sector for 2006. Related emissions were in the order of 1,949,224 tonnes of $\mathrm{CO}_{2} \mathrm{e}$ (SMA-DF 2008: 45). In 2010 energy consumption was calculated to be 33 PJ, with average per capita annual emissions of $105 \mathrm{~kg}$ of $\mathrm{CO}_{2} \mathrm{e}$ (SMA-DF 2012). ${ }^{16}$ If the current population of 21 million people in the metropolitan area is taken into consideration, emissions from heating water should be rounded to 2.2 million tonnes of $\mathrm{CO}_{2}$.

Meanwhile, emissions related to the consumption of bottled water, including manufacturing, packing, and distribution, reached 362,400 tonnes of $\mathrm{CO}_{2} \mathrm{e}$ per year at the city level and 900,900 tonnes of $\mathrm{CO}_{2} \mathrm{e}$ per year at the metropolitan level. ${ }^{17}$ In addition, plastic waste generated by the consumption of bottled water reached 80,351 tonnes at the city level and 199,742.4 tonnes at the metropolitan level. ${ }^{18}$ This is waste that must be collected and recycled or disposed of, as the case may be - all actions that demand significant

\footnotetext{
${ }^{14}$ Calculation based on two different methodologies used for estimating electricity production-related GHG emissions in Mexico: 1) the National Commission on Efficient Energy Use approach which estimates emissions at 0.5827 tonnes of $\mathrm{CO}_{2} \mathrm{e} / \mathrm{MWh}$ based on electric power consumption, and 2) the Programa México approach that estimates emissions at $0.498 \mathrm{t}$ of $\mathrm{CO}_{2} \mathrm{e} / \mathrm{MWh}$ based on electrical power generation data (SEMARNAT/INECC 2012: 42).

${ }^{15}$ Calculation derived from SACMEX's estimate, assuming the same emission factors per cubic meter, and considering that CAEM's users are about 60\% of the total users Mexico City Metropolitan Area.

${ }^{16}$ The calculation for both years is based on four showers per week per inhabitant of Mexico City Metropolitan Area using 45 liters per shower (SMA-DF 2008, 2012). This calculation depends on one person's habits: taking six showers per week, using 65 liters of hot water, will instead generate $208 \mathrm{~kg}$ of $\mathrm{CO}_{2} \mathrm{e}$ per year (SMA-DF 2012).

${ }^{17}$ The emissions estimate is based on a factor of $175 \mathrm{~g}$ per liter of bottled water according to information provided by Nestlé-Mexico (Delgado-Ramos 2014b).

${ }^{18}$ Plastic waste generation was estimated at 38.8g (bottle plus secondary packing) per liter of bottled water according to information provided by Nestlé México (Delgado-Ramos 2014b).
} 
amounts of energy. This energy consumption could be decreased or, even better, avoided if tap water was of drinking quality or if other drinking water options were available such as public water fountains. This is a major issue that in Mexico is not considered in mainstream water or climate change policies, despite the clear existence of environmental and health co-benefits (the country also has severe obesity problems) (DelgadoRamos ed. 2014).

Likewise, avoided emissions due to the use of 'black water' or wastewater through a process that recovers nutrients (phosphorus and nitrogen) have been estimated at some 414,500 tonnes of $\mathrm{CO}_{2}$ e for both the cropland area of Tula and of the Valley of Mexico. ${ }^{19}$ Recovery means that these elements no longer need to be industrially synthesized. In this context, it must be pointed out that although there are methods for safely using wastewater (Duncan and Cairncross 1989), these certainly are not implemented in the case under review. $^{20}$

Taking into consideration that total GHG emissions from the metropolitan water-energy nexus described above reach some 5.5 million tonnes of $\mathrm{CO}_{2} \mathrm{e}$ annually (or $10 \%$ of total metropolitan GHG emissions officially reported for 2010 ${ }^{21}$, it seems evident that water management planning should include all the complexity of urban water metabolism dynamics in order to generate smarter and integrated mitigation solutions at diverse spatial scales and timeframes, but also for achieving better (water) systemic outcomes, synergies and co-benefits, including those of social justice.

In relation to the last issue, it is worth pointing out the palpable asymmetries in the spatial allocation of GHG emissions attributable to the whole water urban metabolic flow (WUMF), excluding avoided emissions from the use of wastewater in agriculture. Table 2 presents an estimate for Mexico City's boroughs (not at the metropolitan scale). Co-benefits can be particularly significant in terms of electricity generation from methane capture and thus for climate mitigation; land and water conservation through reducing plastic pollution and thus bottled water consumption (but also by effectively protecting conservation land and promoting reforestation programs); avoiding GHG emissions by properly using wastewater for crop production (which means taking the necessary precautions for protecting health and the environment).

\section{Discussion: a focus on new paradigms}

The possibility of transforming urban settlements in developed countries is incomparably greater than that of developing ones, not only because they have greater means of economic and technological innovation, but also because many hidden or indirect socio-environmental and climate costs are 'exported' or internationalized (all cities do this in one way or another using their own hinterland).Therefore, urbanization in developing countries tends to be more problematic and complex due to a limited or overburdened capacity to take measures and actions, a scenario in which urban poverty is an enormous challenge to developing a more human and sustainable urban reconfiguration.

The design and execution of public policies needed for transforming the current trend of constructing, operating, managing, and living in cities must be proactive, imaginative, and based on an integral metabolic planning. Accordingly, urban metabolic analyses seem to be essential policy tools, but in general urban planning (which includes land planning) can be adjusted to overarching contextual changes and to historical trends and socially desirable futures. If these actions commence with the aforementioned integrated planning with social justice, the sum of multiple actions, may have a heightened impact while allowing synergies and co-benefits of various types to develop (Seto et al. 2014). Consequently, traditional sector-based management is no longer sufficient or viable.

\footnotetext{
${ }^{19}$ Wastewater contains 97\% water and 3\% solid materials (organic and inorganic). The following are the factors used in calculating emissions: $6.41 \mathrm{~kg}$ of $\mathrm{CO}_{2} \mathrm{e}$ per kilogram of nitrogen and $1.18 \mathrm{~kg}$ of $\mathrm{CO}_{2} \mathrm{e}$ per kilogram of phosphorus (based on estimates by García et al. 2011).

${ }^{20}$ For instance, it is well known that treatment processes are indeed required to remove toxic substances and pathogens before any irrigation can take place. Nonetheless, as already described, treatment capacity of Mexico City Metropolitan Area is still extremely low.

${ }^{21}$ Total 2010 emissions for Mexico City Metropolitan Area were 54,700 Gg of $\mathrm{CO}_{2}$ e (SMA-DF 2012).
}

Journal of Political Ecology Vol. 22, 2015 


\begin{tabular}{|c|c|c|c|}
\hline $\begin{array}{c}\text { Borough } \\
\text { (population - 2010) }\end{array}$ & 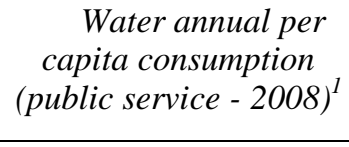 & $\begin{array}{l}\text { Annual GHG per } \\
\text { capita emissions from } \\
W U F M(\mathrm{~kg})^{2}\end{array}$ & $\begin{array}{l}\text { Borough's annual } \\
\text { GHG emissions } \\
\text { from WUFM - } \\
\text { tonnes } \\
\end{array}$ \\
\hline $\begin{array}{c}\text { Azcapotzalco } \\
(414,711)\end{array}$ & 118,990 & 302.28 & $125,358.84$ \\
\hline $\begin{array}{l}\text { Álvaro Obregón } \\
(727,034)\end{array}$ & 142,715 & 343.77 & $249,932.47$ \\
\hline $\begin{array}{c}\text { Benito Juárez } \\
(385,439)\end{array}$ & 166,075 & 384.63 & $148,251.40$ \\
\hline $\begin{array}{l}\text { Coyoacán } \\
(620,416) \\
\end{array}$ & 113,880 & 293.34 & $181,992.83$ \\
\hline $\begin{array}{l}\text { Cuauhtémoc } \\
(531,831)\end{array}$ & 175,200 & 400.59 & $213,046.18$ \\
\hline $\begin{array}{c}\text { Cuajimalma } \\
(186,391)\end{array}$ & 191,625 & 429.32 & $80,021.38$ \\
\hline $\begin{array}{l}\text { Gustavo A } \\
\text { Madero } \\
(1,185,772)\end{array}$ & 125,195 & 313.13 & $371,300.78$ \\
\hline $\begin{array}{l}\text { Iztacalco } \\
(384,326) \\
\end{array}$ & 115,705 & 296.53 & $113,964.18$ \\
\hline $\begin{array}{c}\text { Iztapalapa } \\
(1,815,786)\end{array}$ & 86,870 & 246.10 & $446,864.93$ \\
\hline $\begin{array}{l}\text { Magdalena } \\
\text { Contreras } \\
(239,086)\end{array}$ & 151,110 & 358.46 & $85,702.76$ \\
\hline $\begin{array}{l}\text { Miguel Hidalgo } \\
(372,889)\end{array}$ & 174,470 & 399.31 & $148,898.30$ \\
\hline $\begin{array}{c}\text { Milpa Alta } \\
(130,582)\end{array}$ & 84,315 & 241.63 & $31,552.52$ \\
\hline $\begin{array}{c}\text { Tláhuac } \\
(360,567) \\
\end{array}$ & 64,605 & 207.16 & $74,695.05$ \\
\hline $\begin{array}{c}\text { Tlalpan } \\
(650,567) \\
\end{array}$ & 90,885 & 253.12 & $164,671.51$ \\
\hline $\begin{array}{c}\text { Venustiano } \\
\text { Carranza }(430,978) \\
\end{array}$ & 123,005 & 309.30 & $133,301.49$ \\
\hline $\begin{array}{l}\text { Xochimilco } \\
(415,007)\end{array}$ & 78,110 & 230.78 & $95,775.31$ \\
\hline \multicolumn{3}{|c|}{ TOTAL GHG EMISSIONS: } & 2,665,329.93 \\
\hline \multicolumn{4}{|c|}{$\begin{array}{l}{ }^{*} \text { WUMF: water urban metabolic flow } \\
{ }^{1} \text { Includes leakages. Total water consumption in } 2008 \text { was higher than in } 2013 \text {. In } 2008 \text { total water inflow } \\
\text { accounted for about } 1,047,360 \text { million liters. } \\
{ }^{2} \text { The lowest estimation of GHG emissions for SACMEX's operations of } 0.298 \mathrm{~g} \text { of } \mathrm{CO}_{2} \text { e per liter; } 0.887 \mathrm{~g} \\
\text { of } \mathrm{CO}_{2} \mathrm{e} \text { from water heating per liter (total GHG emissions from heating of about } 929,250 \text { tonnes of } \mathrm{CO}_{2} \mathrm{e} \\
\text { have been divided per total city's water inflow of } 2008 \text { in order to allocate such emissions to water } \\
\text { consumption shares); } 0.564 \mathrm{~g} \text { of } \mathrm{CO}_{2} \mathrm{e} \text { from wastewater methane emissions per liter (total Mexico City's } \\
\mathrm{CH}_{4} \text { emissions of } 591,000 \text { tonnes of } \mathrm{CO}_{2} \mathrm{e} \text { have been divided per total city's water inflow of } 2008 \text { in order } \\
\text { to allocate such emissions to water consumption shares and thus, moving the responsibility of wastewater } \\
\text { production to water consumers); and } 94.17 \text { kg of } \mathrm{CO}_{2} \mathrm{e} \text { per capita yearly from bottled water consumption } \\
\text { (average national data). }\end{array}$} \\
\hline
\end{tabular}

Table 2. Spatial allocation of GHG emissions related to Mexico City's metabolic water flow. Source: author's own elaboration based on Jiménez et al., 2011 and estimations on water metabolic flow GHG emissions presented in this paper.

Even more important, a profound transformation of existing urban settlements demands, not only consideration of the urban design form and its metabolic profile, but also a profound reformulation of the urban territorial function or the purposes of urban territorial configuration. This means moving from schemes 
that make capital accumulation a priority, to those that promote human development or living well. In that sense, and as Swyngedouw et al. (2005) correctly claim, it is crucial to ask who produces what type of urban configuration, who gains and who loses and in what ways, and who benefits and who suffers from particular urban territorial configurations (within and beyond the cities). Likewise, given that the construction of space is dynamic, it is equally important to understand the future perspectives of each approach, and how each approach provides, or does not provide, alternatives (as well as alternatives to what) based on certain cultural, historical and environmental notions. We are currently in a position in which technological solutions regarding the type and design of infrastructure play a part, but also in which a deep-seated change in prevailing logic and, therefore, the nature and desirability of the solutions themselves, is crucial.

In the specific case of the hydrosocial cycle of Mexico City Metropolitan Area, the challenge is pronounced. In spite of the fact that the population is growing slowly in the area that is already urbanized (but there has been a significant increase in some municipalities of the conurbation), there is a confirmed need for $1 \mathrm{~m}^{3} / \mathrm{s}$ of additional water by 2015 alone. This represents a demand managed against a backdrop of a decreasing flow rate in supply of $3 \mathrm{~m}^{3} / \mathrm{s}$ over the past decade. Therefore, it is clear that in the coming years the highest pressure will be seen in the conurbanized area, although changes in social expectations regarding the amount and especially the quality of water could also pose significant challenges for the supply system (Jiménez et al. 2011).

In recognition of the fact that the availability of water has already reached its maximum viable point in spite of all technological innovations and large infrastructure development, one disputed proposal suggests expanding the water system into more remote regions. The fourth phase of the Cutzamala system, for example, is aimed at making use of the high-altitude Tula, Tecolutla, Valle del Mezquital, and Amacuzac rivers, which in most cases will yield comparatively lesser volumes of lower-quality treated water.

A long-term solution cannot be that simple, nor can it be merely or mainly centered on large-scale engineering solutions. The so-called 'new water culture' centered around a moderate and responsible, though socially fair consumption, is certainly an important issue, but there are others as well. These include addressing the issue of leaks in present and future systems; attempting to effectively plan the use of land, especially peripheral urban land; protecting conservation areas while restoring their vegetation as well as that of the city itself for the purpose of, among others, increasing evapotranspiration capacity and reducing city temperature. Given the heterogeneity of water conditions and territorial infrastructure that hinder the ideal homogeneity of the equal supply of water in terms of quantity, quality, and frequency throughout the entire Valley of Mexico, it is also desirable to decentralize the water system by promoting other systems at multiple spatial scales. This could include rainwater harvesting and local water reuse/treatment - that might increase the flexibility, transformation, and resilience of the whole system in the face of external shocks, including those resulting from climate change.

\section{Conclusion}

New paradigms for managing water that are more fair from a social and ecological perspective and that are more harmonious in the short, medium, and long term, demand a combination of new technologies, practices (including planning and regulation), and values that must be developed and implemented by all inhabitants, including the social, political, and economic players in each territory. This process is feasible, though certainly slow due to 'infrastructure lock-in' (to certain metabolic dynamics and patterns) and to the persistent nature of practices and interests grounded in traditional management criteria.

A genuinely bottom-up management of water infrastructure (and certainly of the urban built environment as a whole), which goes further than just citizens' participation, is and will be of more importance in future. It will allow a formulation new ways of democratic self-management, with a sense of community. This is a scenario of genuine participative democracy, which, from a broader perspective, must be viewed as a mechanism for empowering the people inhabiting the same territories for the purpose of guaranteeing human rights, such as the right to water and sanitation or a healthy environment, but also for supporting peoples' right to a fair city. 


\section{References}

Angel S., J. Parent, D.L. Civco, A. Blei, and D. Potere. 2011. The dimensions of global urban expansion: estimates and projections for all countries, 2000-2050. Progress in Planning 75: 53-107.

Aponte Hernández, N.O. 2013. Metodología para evaluar la disponibilidad del agua para uso muncipal y sus costos bajo los escenarios de cambio climático. Master dissertation, Posgrado de Ingeniería. Programa de Posgrado en Ingeniería Ambiental. Mexico: UNAM.

Ávila-García, P. 2011. Water conflicts and human rights in indigenous territories of Latin America. Rosenberg International Forum on Water Policy. [accessed March 29 2014] http://ciwr.ucanr.edu/files/168776.pdf

Baccini, P. and P. Brunner. 1990. Metabolism of the Anthroposphere. First Edition. Cambridge, MA: MIT Press.

Baccini, P. and P. Brunner. 2012. Metabolism of the Anthroposphere. Second Edition. Cambridge, MA: MIT Press.

Brunner, P. and H. Rechberger. 2005. Practical handbook of material flow analysis. Florida: Lewis Publishers.

Burns, E. (ed.). 2009. Repensar la cuenca: la gestión de los ciclos del agua en el Valle de México. Mexico: UAM-X/USAID.

CONAGUA, 2014. Planta de tratamiento de aguas residuales Atotonilco. CONAGUA Website [accessed March 29 2014]. www.conagua.gob.mx/sustentabilidadhidricadelValledeMexico/ProyectoDrenajes.aspx?Pag=3

Delgado-Ramos, G.C. 2013. Climate change and metabolic dynamics in Latin American major cities. In Zubir S.S. and C.A. Brebbia (eds). Sustainable city VIII: urban regeneration and sustainability. Southampton, UK: WIT Press. Pp. 39 -56.

Delgado-Ramos, G.C. 2014a. Ciudad, agua y cambio climático. Una aproximación desde el metabolismo urbano. Medio Ambiente y Urbanización 80 (1): 95-123.

Delgado-Ramos, G.C. 2014b. El negocio del agua embotellada. Realidad Económica 281: 24 -42.

Delgado-Ramos, G.C. (ed.). 2014. Apropiación de agua, medio ambiente y obesidad. Los impactos del negocio de bebidas en México. Mexico: CEIICH-UNAM.

Delgado-Ramos, G.C., C. Campos-Chávez and P. Rentería-Juárez. 2012. Cambio climático y el metabolismo urbano de las megaurbes latinoamericanas. Hábitat Sustentable 2 (1): 2 - 25.

Díaz Álvarez, C.J. 2011. Metabolismo de la Ciudad de Bogotá: una herramienta para el análisis de la sostenibilidad ambiental urbana. Bogota: Universidad Nacional de Colombia.

Díaz-Santos, M.G. 2012. Implicaciones sociales de los contratos al sector privado en el servicio de agua potable en la Ciudad de México. Bachelor dissertation, Faculty of Political and Social Sciences. Mexico: UNAM.

Dobbs, R., H. Pohl, L. Diaan-Yi, J. Mischke, N. Garemo, J. Hexter, S. Matzinger, R. Palter and R. Nanavatty. 2013. Infrastructure productivity: how to save \$1 trillion a year. USA: McKinsey Global Institute.

Duncan, M. and S. Cairncross. 1989. Guidelines for the safe use of wastewater and excreta in agriculture and aquaculture. Geneva: World Health Organization.

Ferrão, P. and J. Fernández. 2013. Sustainable urban metabolism. Cambridge, MA: MIT Press.

García, C., A. Fuentes, A. Hennecke, E. Riegelhaupt, F. Manzini and O. Masera. 2011. Life-cycle greenhouse gas emissions and energy balances of sugarcane ethanol production in Mexico. Applied Energy 88 (6): 2088-2097.

Haberl, H. 2001. The energetic metabolism of societies: part I: accounting concepts. Journal of Industrial Ecology 1(5): 11-33.

Harvey, D. 1996. Justice, nature and the geography of difference. Oxford, UK: Blackwell.

Harvey, D. 2003. The new imperialism. Oxford: Oxford University Press.

Harvey, D. 2004. El nuevo imperialismo. Madrid: Akal Ediciones. 
INFO-DF. 2014. Dirección ejecutiva de operación. Dirección de Agua Potable y Potabilización. Sistema de aguas de la Ciudad de México. Ofico de solicitud pública: 0324000009414. Mexico.

Jiménez Cisneros, B., R. Gutiérrez Rivas, B. Marañón Pimentel and A. González Reynoso. (eds.). 2011. Evaluación de la política de acceso al agua potable en el Distrito Federal. Mexico: PUEC-UNAM.

Jornada, La. 2011. Escasez de aguas negras incuba conflicto en Valle del Mezquital. La Jornada, May $29^{\text {th }}$.

Kennedy, C., J. Cuddihy and J. Engel-Yan. 2007. The changing metabolism of cities. Journal of Industrial Ecology 11(2): 43-59.

Kennedy, C., J. Steinberg, B. Gasson, Y. Hansen, T. Hillman, M. Havránek, D. Pataki, A. Phdungsilp, A. Ramaswami and G. Villalba Méndez. 2009. Methodology for inventorying greenhouse gas emissions from global cities. Energy Policy 38(9): 4828-4837.

Kennedy, C., S. Pinceti and P. Bunje. 2011. The study of urban metabolism and its applications to urban planning and design. Environmental Pollution 159(8-9): 1965 - 1973.

Minx, J., F. Creutzig, V. Medinger, T. Ziegler, A. Owen and G. Baiocchi. 2010. Developing a pragmatic approach to assess urban metabolism in Europe. A report to the European Environment Agency. Copenhagen, Denmark: Stockholm Environment Institute / Technical University of Berlin.

Montoya, J. R. 2013. Acusan de despojo de aguas negras a Edomex y DF. MagazineMx. [Accessed March 29 2014]. www.magazinemx.com/bj/articulos/articulos.php?art=15157

News Hidalgo. 2012. Temen campesinos de Hidalgo, fatla de agua para sus cultivos. News Hidalgo. Mexico. [accessed March 29 2014]. www.newshidalgo.com.mx/?p=4925

Peña-Ramírez, J. 2012. Crisis del agua en Monterrey, Guadalajara, San Luis Potosí, León y la Ciudad de México (1950 - 2010). Mexico: PUEC-UNAM.

Perló, M. and A. González. 2009. ¿¿Guerra por el agua en el Valle de México? Estudio sobre las relaciones hidráulicas entre el Distrito Federal y el Estado de México. Mexico: PUEC-UNAM.

SEDEMA - Secretaría de Medio Ambiente del Gobierno del Distrito Federal. 2014. Inventario de residuos sólidos de la Ciudad de México 2013. Mexico: Gobierno de la Ciudad de México.

SEDEMA - Secretaría de Medio Ambiente del Gobierno del Distrito Federal. 2013. Registro de emisiones de gases de efecto invernadero del Distrito Federal - 2012. Comunidad y Gobierno. Mexico: Gobierno del Distrito Federal.

SEMARNAT/CONAGUA. 2012. inventario nacional de plantas municipales de potabilización y de tratamiento de aguas residuales en operación. Mexico: SEMARNAT/CONAGUA.

SEMARNAT/INECC. 2012. México - Quinta comunicación nacional ante la Convención Marco de las Naciones Unidas sobre el Cambio Climático. México: Gobierno Federal. [accesed March 29 2014]: http://www2.inecc.gob.mx/publicaciones/download/685.pdf

SMA-DF - Secretaría de Medio Ambiente del Distrito Federal. 2008. Inventario de Emisiones de la Zona Metropolitana del Valle de México, 2006. Mexico: Gobierno del Distrito Federal.

SMA-DF - Secretaría de Medio Ambiente del Distrito Federal. 2012. Inventario de emisiones de la Zona Metropolitana del Valle de México, 2010. Mexico: Gobierno del Distrito Federal.

SENER - Secretaría de Energía. 2013. Calentador de agua. Comisión Nacional para el Uso Eficiente de la Energía Website [accessed May 25 2014]: www.conuee.gob.mx/wb/CONAE/calentadores de agua

Seto K. C., S. Dhakal, A. Bigio, H. Blanco, G.C. Delgado, D. Dewar, L. Huang, A. Inaba, A. Kansal, S. Lwasa, J. E. McMahon, D. B. Müller, J. Murakami, H. Nagendra, and A. Ramaswami. 2014. Human settlements, infrastructure and spatial planning. In O. Edenhofer, R. Pichs-Madruga, Y. Sokona, E. Farahani, S. Kadner, K. Seyboth, A. Adler, I. Baum, S. Brunner, P. Eickemeier, B. Kriemann, J. Savolainen, S. Schlömer, C. von Stechow, T. Zwickel and J.C. Minx (eds.) Climate change 2014: mitigation of climate change. Contribution of Working Group III to the Fifth Assessment Report of the Intergovernmental Panel on Climate Change. Cambridge: Cambridge University Press. 
Swyngedouw, E., N. Heynen and M. Kaika. 2005. Urban political ecology: politicising the production of urban natures. In Swyngedouw E., N. Heynen and M. Kaika (eds.) $\underline{I n}$ the nature of cities: urban political ecology and the politics of urban metabolism. London, UK: Routledge.

United Nations. 2012. World urbanization prospects, the 2011 revision. Department of Economic and Social Affairs. Population Division. New York, USA: United Nations.

Wolman, A. 1965. The metabolism of cities. Scientific American 213(3): 179-190.

Zhang, Y. 2013. Urban metabolism: a review of research methodologies. Environmental Pollution 178: 463473. 